\title{
PENGARUH BERBAGAI DOSIS BOKASHI DAN KONSENTRASI PUPUK ORGANIK CAIR KIRINYUH (Chromolaena odorata)TERHADAP PERTUMBUHAN DAN HASIL TANAMAN JAGUNG (Zea mays L.) KULTIVAR PIONEER
}

\author{
Arrum Adhieman Ningrum ${ }^{1)}$, Jenal Mutakin ${ }^{2)}$, Kiki Zakiah ${ }^{2)}$ \\ 1) Mahasiswa Fakultas Pertanian Universitas Garut \\ ${ }^{2)}$ Dosen Fakultas Pertanian Universitas Garut \\ E-mail :kiki.alzakia@gmail.com
}

\begin{abstract}
ABSTRAK
Percobaan dilaksanakan di Kampung Panoongan Desa Cinunuk Kecamatan Wanaraja Kabupaten Garut, dengan ketinggian 672-730 meter di atas permukaan laut, dengan $\mathrm{pH}$ 5,7. Tipe curah hujan berdasarkan klasifikasi curah hujan Schmidt dan Ferguson (1951) termasuk tipe curah hujan C. Percobaan dilaksanakan pada Bulan Juni sampai September 2017. Tujuan penelitian adalah mempelajari sejauh mana pengaruh interaksi dosis bokashi dan konsentrasi pupuk organik cair kirinyuh terhadap pertumbuhan dan hasil tanaman jagung kultivar pioneer. Metode yang digunakan dalam penelitian adalah eksperimental dengan menggunakan Rancangan Acak Kelompok (RAK) pola faktorial 3 x 3 dengan 3 kali ulangan. Faktor pertama dosis bokashi (B) terdiri dari tiga taraf perlakuan, yaitu: $\mathrm{b}_{0}=0$ ton/ha setara dengan $0 \mathrm{~kg} / \mathrm{plot}, \mathrm{b}_{1}=15$ ton $/$ ha setara dengan $6 \mathrm{~kg} / \mathrm{plot}, \mathrm{b}_{2}=20$ ton $/$ ha setara dengan 8 $\mathrm{kg}$ /plot. Faktor kedua konsentrasi pupuk organik cair kirinyuh $(\mathrm{K})$ terdiri dari tiga taraf perlakuan, yaitu: $\mathrm{k}_{0}=$ tanpa pupuk organik cair kirinyuh, $\mathrm{k}_{1}=100 \mathrm{ml} /$ liter air, $\mathrm{k}_{2}=200 \mathrm{ml} /$ liter air. Hasil penelitian menunjukan terjadi interaksi antara berbagai dosis bokashi dan konsentrasi pupuk organik cair kirinyuh terhadap tinggi tanaman $42 \mathrm{HST}$, dan bobot tongkol. Kombinasi terbaik ditunjukan pada perlakuan $\mathrm{b}_{2} \mathrm{k}_{2}$ yaitu 20 ton/ha setara dengan $8 \mathrm{~kg} /$ plot dan $200 \mathrm{ml} /$ liter air. Secara mandiri, dosis bokashi 20 ton/ha setara dengan $8 \mathrm{~kg} /$ plot menunjukan pengaruh terbaik terhadap tinggi tanaman 14 HST dan 28 HST, luas daun, bobot kering, diameter tongkol dan panjang tongkol. Sementara pada konsentrasi pupuk organik cair kirinyuh pada dosis $200 \mathrm{ml} /$ liter air menunjukan pengaruh terbaik terhadap tinggi tanaman, luas daun, bobot kering, diameter tongkol, panjang tongkol.
\end{abstract}

Kata kunci: Bokashi, Pupuk Organik Cair Kirinyuh, Jagung 


\section{PENDAHULUAN}

Jagung (Zea mays L.) merupakan salah satu bahan pangan yang penting di Indonesia karena jagung merupakan sumber karbohidrat setelah beras. Jagung juga merupakan bahan baku industri dan pakan ternak. Produktivitas jagung yang rendah disebabkan banyak jagung dibudidayakan di lahan kering. Umumnya, lahan kering mempunyai kandungan bahan C-organik yang rendah $(<1 \%)$ kandungan bahan Corganik yang rendah menyebabkan kesuburan tanah berkurang (Adiningsih, 1988).

Pertumbuhan tanaman yang baik dapat dicapai dengan mempertahankan syarat-syarat tumbuh dan pemeliharaannya di antaranya dengan pemupukan. Pupuk organik merupakan solusi yang tepat untuk mensubtitusikan pupuk anorganik. Pupuk organik dapat dibedakan atas pupuk organik padat dan cair. Salah satu bahan organik yang dapat digunakan adalah bokashi. Bokashi merupakan hasil fermentasi bahan organik dari limbah pertanian (pupuk kandang, jerami, sampah, sekam, serbuk gergaji) dengan menggunakan EM-4 (Atikah, 2013).

Selain bokashi, terdapat jenis pupuk lain yang bisa dimanfaatkan yaitu Pupuk Organik Cair (POC). Pupuk organik cair dapat secara cepat mengatasi kekurangan unsur hara. Pupuk organik cair umumnya tidak merusak tanah dan tanaman walaupun digunakan sesering mungkin. Pupuk organik cair dapat berasal dari bahan-bahan organik seperti kotoran ternak, limbah padat pertanian, tumbuhan air dan lain sebagainya.

\section{METODE PENELITIAN}

Percobaan dilaksanakan di Kampung Panoongan Desa Cinunuk Kecamatan Wanaraja Kabupaten Garut. Daerah tersebut memiliki ketinggian 672-730 m dpl, dengan $\mathrm{pH}$ tanah 5,7. Percobaan dilaksanakan pada bulan Juni sampai September 2017.

Metode yang digunakan dalam Percobaan ini menggunakan metode eksperimental dengan Rancangan Acak Kelompok (RAK) pola faktorial 3x3 dengan tiga kali ulangan. Faktor pertama dosis bokashi (B) dengan 3 taraf, yaitu:

$\mathrm{B}_{0} \quad=0$ ton $/$ ha setara dengan $0 \mathrm{~kg} / \mathrm{plot}$

$\mathrm{B}_{1}=15$ ton $/$ ha setara dengan $6 \mathrm{~kg} / \mathrm{plot}$

$\mathrm{B}_{2}=20$ ton/ha setara dengan $8 \mathrm{~kg} / \mathrm{plot}$

Faktor kedua konsentrasi pupuk organik cair kirinyuh (K) dengan tiga taraf yaitu:

$\mathrm{K}_{0} \quad=$ tanpa pupuk organik cair kirinyuh

$\mathrm{K}_{1}=100 \mathrm{ml} /$ liter air

$\mathrm{K}_{2}=200 \mathrm{ml} / \mathrm{liter}$ air 
Pengamatan dilakukan dengan mengamati komponen pertumbuhan dan hasil untuk mengetahui pengaruh setiap perlakuan diantaranya tinggi tanaman, luas daun, bobot kering pertanaman, panjang tongkol tanpa kelobat, berat tongkol tanpa kelobat dan diameter tongkol tanpa kelobat.

\section{HASIL DAN PEMBAHASAN}

\section{Tinggi Tanaman}

Hasil analisis statistik menunjukkan tidak terjadi interaksi antara berbagai dosis bokashi dan konsentrasi pupuk organik cair kirinyuh terhadap tinggi tanaman jagung kultivar pioneer pada setiap periode pengamatan, namun secara mandiri terjadi perbedaan yang nyata (Tabel 1).

Tabel 1. Hasil Analisis Tinggi Tanaman 14 HST dan 28 HST

\begin{tabular}{lcc}
\hline \multicolumn{1}{c}{ Perlakuan } & \multicolumn{2}{c}{ Rata-rata tinggi tanaman $(\mathbf{c m})$} \\
\cline { 2 - 3 } & 14 HST & 28 HST \\
\hline Dosis Bokashi & $20,39 \mathrm{a}$ & $51,62 \mathrm{a}$ \\
b0 = 0 ton/ha setara $0 \mathrm{~kg} /$ plot & $20,87 \mathrm{a}$ & $52,80 \mathrm{a}$ \\
$\mathrm{b}_{1}=15$ ton/ha setara $6 \mathrm{~kg} / \mathrm{plot}$ & $21,79 \mathrm{~b}$ & $53,67 \mathrm{~b}$ \\
$\mathrm{~b}_{2}=20$ ton/ha setara $8 \mathrm{~kg} / \mathrm{plot}$ & \\
konsentrasi Pupuk Organiik cair kirinyuh & & \\
$\mathrm{k}_{0}=$ Tanpa POC Kirinyuh & $20,05 \mathrm{a}$ & $50,55 \mathrm{a}$ \\
$\mathrm{k}_{1}=100 \mathrm{ml} /$ liter air & $21,21 \mathrm{~b}$ & $52,65 \mathrm{a}$ \\
$\mathrm{k}_{2}=200 \mathrm{ml} /$ liter air & $21,78 \mathrm{~b}$ & $54,89 \mathrm{~b}$ \\
\hline
\end{tabular}

Keterangan : Angka rata-rata yang diikuti huruf yang sama pada setiap kolom, tidak berbeda nyata menurut Uji Jarak Berganda Duncan pada taraf nyata $5 \%$.

Peningkatan tinggi tanaman terjadi seiring dengan peningkatan pemberian dosis bokashi. Keadaan ini membuktikan bahwa perlakuan 20 ton/ha telah mampu memacu pertumbuhan tinggi tanaman sampai titik optimum. Hal ini disebabkan oleh kandungan $\mathrm{N}$ pada bokashi yang tinggi dalam penelitian Sirajuddin dan Lasmini, (2010) dinyatakan bahwa pemberian pupuk Nitrogen pada tanaman jagung merupakan hal yang sangat penting karena Nitrogen dapat meningkatkan protein dan asam amino pada tanaman, membantu pertumbuhan vegetatif sehingga daun jagung tumbuh dengan baik. Protein memiliki peran dalam fungsi mekanis misalnya pembentukan batang.

Pupuk organik cair kirinyuh merupakan pupuk yang memiliki kandungan unsur hara makro dan mikro yang berguna memacu pertumbuhan karena masing masing unsur yang terkandung di dalamnya memiliki peran tersendiri bagi tanaman 
dalam proses metabolisme tanaman. Kecukupan unsur hara $\mathrm{N}$ akan menunjukan pertumbuhan vegetatif lebih baik dibandingkan tanaman yang kekurangan unsur $\mathrm{N}$.

\section{Tinggi Tanaman 42 HST}

Hasil analisis statistik menunjukkan terjadi interaksi antara berbagai dosis bokashi dan konsentrasi pupuk organik cair kirinyuh terhadap tinggi tanaman jagung kultivar pioneer pada umur 42 HST.

Tabel 2. Hasil Analisis Tinggi Tanaman 42 HST

\begin{tabular}{|c|c|c|c|}
\hline \multirow{3}{*}{ Perlakuan } & \multicolumn{3}{|c|}{ Rata-rata Tinggi Tanaman 42 HST } \\
\hline & $\mathbf{k}_{\mathbf{0}}$ & $\mathbf{k}_{1}$ & $\mathbf{k}_{2}$ \\
\hline & (Tanpa Pupuk Organik cair) & (100 ml / Liter air) & (200 ml / liter air ) \\
\hline $\mathrm{b}_{0}=0$ ton $/ \mathrm{ha}$ & $98,67 \mathrm{a}$ & $106,47 \mathrm{a}$ & $104,74 \mathrm{a}$ \\
\hline$(0 \mathrm{~kg} / \mathrm{plot})$ & A & A & A \\
\hline $\mathrm{b}_{1}=15$ ton $/ \mathrm{ha}$ & $104,52 \mathrm{a}$ & $112,22 \mathrm{a}$ & $116,09 \mathrm{~b}$ \\
\hline$(6 \mathrm{~kg} / \mathrm{plot})$ & A & A & B \\
\hline $\mathrm{b}_{2}=20$ ton $/ \mathrm{ha}$ & $106,77 \mathrm{a}$ & $110,03 \mathrm{a}$ & $124,03 \mathrm{~b}$ \\
\hline$(8 \mathrm{~kg} / \mathrm{plot})$ & A & A & B \\
\hline
\end{tabular}

Keterangan: Angka rata-rata yang diikuti huruf yang sama (huruf kecil arah vertikal dan huruf besar arah horizontal) menunjukan tidak berbeda nyata menurut Uji Jarak Berganda Duncan pada taraf nyata $5 \%$.

Kombinasi perlakuan yang menghasilkan nilai rata-rata tinggi tanaman terendah ditunjukan pada perlakuan 0 ton/ha setara dengan $0 \mathrm{~kg} / \mathrm{plot}$ dan tanpa pupuk organik cair kirinyuh $\left(\mathrm{b}_{0} \mathrm{k}_{0}\right)$ dengan angka 98,67 sedangkan nilai rata-rata tertinggi ditunjukan oleh perlakuan 20 ton/ha setara dengan $8 \mathrm{~kg} / \mathrm{plot}\left(\mathrm{b}_{2} \mathrm{k}_{2}\right)$ dengan angka 124,03. Pemberian dosis bokashi 20 ton/ha dan konsentrasi pupuk organik cair kirinyuh $200 \mathrm{ml} / \mathrm{liter}$ air telah mampu mensuplai unsur hara yang diserap tanaman terutama unsur $\mathrm{N}$.

\section{Luas Daun}

Hasil analisis statistik menunjukkan tidak terjadi interaksi antara berbagai dosis bokashi dan konsentrasi pupuk organik cair kirinyuh terhadap luas daun tanaman jagung kultivar pioneer pada setiap periode pengamatan, namun secara mandiri terjadi perbedaan yang nyata (Tabel 3). 
Tabel 3. Analisis Data Luas Daun

\begin{tabular}{lc}
\hline \multicolumn{1}{c}{ Perlakuan } & $\begin{array}{c}\text { Rata-Rata Luas Daun Per Tanaman } \\
\left(\mathbf{c m}^{2}\right)\end{array}$ \\
\hline Dosis Bokashi & $628,68 \mathrm{a}$ \\
$\mathrm{b}_{0}=0$ ton/ha setara $0 \mathrm{~kg} / \mathrm{plot}$ & $678,93 \mathrm{~b}$ \\
$\mathrm{~b}_{1}=15$ ton/ha setara $6 \mathrm{~kg} / \mathrm{plot}$ & $689,48 \mathrm{~b}$ \\
$\mathrm{~b}_{2}=20$ ton/ha setara $8 \mathrm{~kg} / \mathrm{plot}$ & \\
\hline Konsentrasi Pupuk Organiik cair & \\
kirinyuh & $643,45 \mathrm{a}$ \\
$\mathrm{k}_{0}=$ Tanpa pupuk Organik Cair & $663,04 \mathrm{~b}$ \\
Kirinyuh & $690,59 \mathrm{c}$ \\
$\mathrm{k}_{1}=100 \mathrm{ml} /$ liter air & \\
$\mathrm{k}_{2}=200 \mathrm{ml} /$ liter air & \\
\hline Keterangan : Angka rata-rata yang diikuti huruf yang sama pada setiap kolom, \\
$\quad$ tidak berbeda nyata menurut Uji Jarak Berganda Duncan pada taraf \\
$\quad$ nyata $5 \%$.
\end{tabular}

Menurut Ninja et al. (2012), semakin luas permukaan daun maka intensitas sinar matahari yang diterima semakin besar, dan klorofil pada daun yang berfungsi menangkap energi matahari akan meningkatkan laju fotosintesis sehingga semakin banyak karbohidrat yang dihasilkan untuk pembelahan sel dan menyebabkan daun tumbuh lebih besar dan lebar, sehingga berpengaruh terhadap berat segar bagian atas tanaman.

\section{Bobot Kering Tanaman}

Hasil analisis statistik menunjukkan tidak terjadi interaksi antara berbagai dosis bokashi dan konsentrasi pupuk organik cair kirinyuh terhadap bobot kering tanaman jagung kultivar pioneer pada setiap periode pengamatan, namun secara mandiri terjadi perbedaan yang nyata (Tabel 4).

\section{Tabel 4. Analisis Data Bobot Kering Tanaman}

Perlakuan

Rata-Rata Bobot Kering Tanaman (g)

\begin{tabular}{lc}
\hline Dosis Bokashi & \\
$\mathrm{b}_{0}=0$ ton/ha setara $0 \mathrm{~kg} / \mathrm{plot}$ & $84,16 \mathrm{a}$ \\
$\mathrm{b}_{1}=15$ ton/ha setara $6 \mathrm{~kg} / \mathrm{plot}$ & $99,11 \mathrm{a}$ \\
$\mathrm{b}_{2}=20$ ton/ha setara $8 \mathrm{~kg} / \mathrm{plot}$ & $129,04 \mathrm{~b}$ \\
\hline Konsentrasi Pupuk Organiik cair kirinyuh & \\
$\mathrm{k}_{0}=$ Tanpa pupuk Organik Cair Kirinyuh & $82,52 \mathrm{a}$ \\
$\mathrm{k}_{1}=100 \mathrm{ml} /$ liter air & $106,65 \mathrm{a}$ \\
$\mathrm{k}_{2}=200 \mathrm{ml} /$ liter air & $123,14 \mathrm{~b}$ \\
\hline
\end{tabular}


Keterangan : Angka rata-rata yang diikuti huruf yang sama pada setiap kolom, tidak berbeda nyata menurut Uji Jarak Berganda Duncan pada taraf nyata $5 \%$.

Tjondronegoro $d k k$ (1999) menjelaskan bahwa pertumbuhan tanaman berlangsung pada beberapa bagian tertentu tanaman sebagai akibat pertumbuhan sel di daerah meristem. Pertumbuhan akar, batang dan daun terjadi akibat aktivitas pembelahan sel di meristem yang berlangsung terus menerus. Proses pembelahan sel dilanjutkan dengan pemanjangan dan pembelahan sel, di akhiri oleh diferensiasi sel yang membentuk jaringan dan organ penyusun tanaman. Berdasarkan hasil tersebut dengan meningkatnya perkembangan jaringan dan sel tanaman akan meningkatkan pula bobot kering tanaman yang dihasilkan.

\section{Diameter Tongkol}

Hasil analisis statistik menunjukkan tidak terjadi interaksi antara berbagai dosis bokashi dan konsentrasi pupuk organik cair kirinyuh terhadap diameter tongkol tanaman jagung kultivar pioneer pada setiap periode pengamatan, namun secara mandiri terjadi perbedaan yang nyata (Tabel 5).

Tabel 5. Hasil Analisis Data Diameter Tongkol

\section{Perlakuan}

Rata-Rata Diameter Tongkol

(cm)

\begin{tabular}{ll}
\hline Dosis Bokashi & \\
$\mathrm{b}_{0}=0$ ton/ha setara $0 \mathrm{~kg} / \mathrm{plot}$ & $4,22 \mathrm{a}$ \\
$\mathrm{b}_{1}=15$ ton/ha setara $6 \mathrm{~kg} / \mathrm{plot}$ & $4,34 \mathrm{a}$ \\
$\mathrm{b}_{2}=20$ ton/ha setara $8 \mathrm{~kg} / \mathrm{plot}$ & $4,86 \mathrm{~b}$ \\
\hline Konsentrasi Pupuk Organiik cair & \\
kirinyuh & $4,28 \mathrm{a}$ \\
$\mathrm{k}_{0}=$ Tanpa pupuk Organik Cair Kirinyuh & $4,45 \mathrm{a}$ \\
$\mathrm{k}_{1}=100 \mathrm{ml} /$ liter air & $4,69 \mathrm{~b}$ \\
$\mathrm{k}_{2}=200 \mathrm{ml} /$ liter air & \\
\hline Keterangan : Angka rata-rata yang diikuti huruf yang sama pada setiap kolom, \\
\multicolumn{2}{c}{ tidak berbeda nyata menurut Uji Jarak Berganda Duncan pada taraf } \\
$\quad$ nyata 5\%.
\end{tabular}

Kecukupan tanaman memperoleh unsur hara menyebabkan proses fisiologi yang terjadi pada tanaman lebih meningkat salah satunya adalah proses fotosintesis. Hara yang cukup akan meningkatkan efisiensi fotosintesis sehingga meningkatkan laju pembentukan fotosintat di daun yang selanjutnya ditranslokasikan ke daerah pemanfaatan (sink) antara lain tongkol, dengan demikian banyaknya fotosintat yang 
ditranslokasikan pada tongkol menyebabkan ukuran tongkol bertambah yang dicirikan dengan meningkatnya diameter tongkol.

\section{Panjang Tongkol Tanpa Kelobat}

Hasil analisis statistik menunjukkan tidak terjadi interaksi antara berbagai dosis bokashi dan konsentrasi pupuk organik cair kirinyuh terhadap panjang tongkol tanpa kelobat tanaman jagung kultivar pioneer pada setiap periode pengamatan, secara mandiri terjadi perbedaan yang nyata (Tabel 6).

\section{Tabel 6. Hasil Analisis Data Panjang Tongkol Tanpa Kelobat}

\section{Perlakuan}

\section{Dosis Bokashi}

$\mathrm{b}_{0}=0$ ton $/$ ha setara $0 \mathrm{~kg} / \mathrm{plot}$

$\mathrm{b}_{1}=15 \mathrm{ton} / \mathrm{ha}$ setara $6 \mathrm{~kg} / \mathrm{plot}$

$\mathrm{b}_{2}=20$ ton $/$ ha setara $8 \mathrm{~kg} / \mathrm{plot}$
Rata-Rata Diameter Tongkol

(cm)

$20,46 \mathrm{~b}$

$21,16 \mathrm{c}$

Konsentrasi Pupuk Organiik cair

kirinyuh

$\begin{array}{ll}\mathrm{k}_{0}=\text { Tanpa pupuk Organik Cair Kirinyuh } & 20,20 \mathrm{a} \\ \mathrm{k}_{1}=100 \mathrm{ml} / \mathrm{liter} \text { air } & 20,41 \mathrm{~b} \\ \mathrm{k}_{2}=200 \mathrm{ml} / \mathrm{liter} \text { air } & 20,74 \mathrm{~b}\end{array}$

Keterangan : Angka rata-rata yang diikuti huruf yang sama pada setiap kolom, tidak berbeda nyata menurut Uji Jarak Berganda Duncan pada taraf nyata $5 \%$.

Unsur P berperan sebagai pembentukan akar, mendukung pertumbuhan generatif, meningkatkan daya tahan terhadap penyakit, merangsang pembuahan, mempercepat proses pematangan (Leovini, 2012). Menurut Isrun (2006), peranan phosphor antara lain untuk pengisian biji atau umbi dan meningkatkan pertumbuhan dan hasil tanaman.

Ukuran tongkol yang dihasilkan tanaman jagung berhubungan dengan jumlah biji yang terdapat pada tongkol (Faisal, 2011). Perkembangan sistem perakaran yang baik sangat menentukan pertumbuhan vegetatif tanaman yang pada akhirnya menentukan pula fase reproduktif dan hasil tanaman. Pertumbuhan vegetatif yang baik akan menunjang fase generatif yang baik pula (Hamzah, 2007).

\section{Bobot Tongkol Tanpa Kelobat}

Hasil analisis statistik menunjukkan terjadi interaksi antara berbagai dosis bokashi dan konsentrasi pupuk organik cair kirinyuh terhadap bobot tongkol tanaman jagung kultivar pioneer pada setiap periode pengamatan (Tabel 7) 
Tabel 7. Hasil Analisis Data Bobot Tongkol Tanpa Kelobat

\begin{tabular}{|c|c|c|c|}
\hline \multirow{3}{*}{ Perlakuan } & \multicolumn{3}{|c|}{ Rata-Rata Bobot Tongkol Tanpa Kelobat } \\
\hline & $\mathbf{k}_{\mathbf{0}}$ & $\mathbf{k}_{1}$ & $\mathbf{k}_{2}$ \\
\hline & (Tanpa Pupuk Organik cair) & (100 ml / Liter air) & (200 ml / Liter air ) \\
\hline $\mathrm{b}_{0}=0$ ton $/ \mathrm{ha}$ & $131,47 \mathrm{a}$ & $135,23 \mathrm{a}$ & $138,37 \mathrm{a}$ \\
\hline$(0 \mathrm{~kg} / \mathrm{plot})$ & A & A & A \\
\hline $\mathrm{b}_{1}=15$ ton $/ \mathrm{ha}$ & $133,36 \mathrm{a}$ & $136,09 \mathrm{a}$ & $150,70 \mathrm{~b}$ \\
\hline$(6 \mathrm{~kg} / \mathrm{plot})$ & A & A & B \\
\hline $\mathrm{b}_{2}=20$ ton $/ \mathrm{ha}$ & $138,67 \mathrm{a}$ & $208,67 \mathrm{~b}$ & $252,22 \mathrm{c}$ \\
\hline$(8 \mathrm{~kg} / \mathrm{plot})$ & A & B & $\mathrm{C}$ \\
\hline
\end{tabular}

Keterangan: Angka rata-rata yang diikuti huruf yang sama (huruf kecil arah vertikal dan huruf besar arah horizontal) menunjukan tidak berbeda nyata menurut Uji Jarak Berganda Duncan pada taraf nyata $5 \%$.

Menurut Isrun (2006), hasil jagung dipengaruhi oleh P-tersedia tanah yaitu $85 \%$ bobot tongkol jagung ditentukan oleh perubahan tersebut di atas dan selebihnya ditentukan oleh faktor lain. Hal itu sejalan dengan penelitian Ayunda (2014) phospor dapat memperbesar pembentukan buah, selain itu ketersediaan phospor sebagai pembentuk ATP akan menjamin ketersediaan energi bagi pertumbuhan sehingga pembentukan asimilat dan pengangkutan ke tempat penyimpanan dapat berjalan dengan baik.

\section{KESIMPULAN}

1. Terjadi interaksi antara berbagai dosis bokashi dan konsentrasi pupuk organik cair kirinyuh terhadap tinggi tanaman 42 HST, dan bobot tongkol tanpa kelobat. Kombinasi perlakuan $\mathrm{b}_{2} \mathrm{k}_{2}$ dosis bokashi 20 ton/ha setara dengan 8 $\mathrm{kg} / \mathrm{plot}$ dan konsentrasi pupuk organik cair kirinyuh $200 \mathrm{ml} / \mathrm{liter}$ air memberikan pengaruh paling baik terhadap pertumbuhan dan hasil tanaman jagung kultivar pioneer.

2. Secara mandiri, dosis bokashi 20 ton/ha setara dengan $8 \mathrm{~kg} /$ plot menunjukan pengaruh terbaik terhadap tinggi tanaman 14 HST dan 28 HST, luas daun, bobot kering tanaman, diameter tongkol dan panjang tongkol. Sementara pada konsentrasi pupuk organik cair kirinyuh pada dosis $200 \mathrm{ml} /$ liter air menunjukan pengaruh terbaik terhadap tinggi tanaman 14 HST dan 28 HST, luas daun, bobot kering, diameter tongkol dan panjang tongkol. 


\section{DAFTAR PUSTAKA}

Adiningsih, S. 1988. Peranan Bahan Organik Dalam Meningkatkan Efisiensi Penggunaan Pupuk dan Produksi Tanah. Pusat Penelitian Tanah dan Agroklimat Bogor. Bogor

Atikah, A.T. 2013. Pertumbuhan dan Hasil Tanaman Terung Ungu Varietas Yumi F1 Dengan Pemberian Berbagai Bahan Organik dan Lama Inkubasi Pada Tanah Berpasir. Anterior Jurnal, 12 (2) : 6-12

Ayunda, N. 2014. Pertumbuhan Dan Hasil Tanaman Jagung Manis (Zea mays saccharata Sturt.) Pada Beberapa Konsentrasi Sea Minerals. Skripsi. Fakultas Pertanian, Universitas Tamansiswa. Padang.

Faisal, Bahtiar, A.C Turang. 2011. Kelayakan Uasaha Tani jagung Komposit Varietas Bisma di Tomohon Sulawesi Utara. Serealia 635-641

Hamzah, F. 2007. Pengaruh Penggunaan Pupuk Bokashi kotoran Sapi Terhadap Pertumbuhan dan Produksi Tanaman Jagung. Diakses pada tanggal 14 september 2017.

Isrun. 2006. Pengaruh Dosis Pupuk P dan Jenis Pupuk Kandang Terhadap Beberapa Sifat Kimia tanah, Serapan P dan hasil Jagung Manis (Zea mays var. Saccharata Sturt) Pada Inceptisols Jatinangor. J. Agrisains, 7 No.1: 917.

Leovini, Helena.2012. Pemanfaatan Pupuk Organik Cair Pada Budidaya Tanaman Tomat (Solanum lycopersicum L.). Fakultas Pertanian Universitas Gadjah Mada, Yogyakarta.

Ninja. 2012. Respon Tanaman Kailan Terhadap Pupuk Bokashi Jerami Padi Pada

Tanah Aluvial. Fakultas Pertanian Universitas Tanjungpura, Pontianak

Sirajuddin, M. dan S. A., Lasmini. 2010. Respon Pertumbuhan dan Hasil Jagung Manis (Zea mays Saccharata) Pada Berbagai Waktu Pemberian Pupuk Nitrogen dan Ketebalan Mulsa Jerami. J. Agroland 17 (3) : 184 - 191.

Tjondonegoro, Haran dan Prawiranata. 1999. Fisiologi Tumbuhan Dasar. Fakultas Matematika dan Ilmu Pengetahuan Alam. Institut Pertanian Bogor, Bogor. 